\title{
Philosophiques
}

\section{Illustration : G. Schlosser, Correspondances interloquées, 1994}

Volume 23, numéro 1, printemps 1996

Critères esthétiques et métamorphoses du beau

URI : https://id.erudit.org/iderudit/027360ar

DOI : https://doi.org/10.7202/027360ar

Aller au sommaire du numéro

Éditeur(s)

Société de philosophie du Québec

ISSN

0316-2923 (imprimé)

1492-1391 (numérique)

Découvrir la revue

Citer ce document

(1996). Illustration : G. Schlosser, Correspondances interloquées, 1994.

Philosophiques, 23(1), 13-13. https://doi.org/10.7202/027360ar d'utilisation que vous pouvez consulter en ligne.

https://apropos.erudit.org/fr/usagers/politique-dutilisation/ 


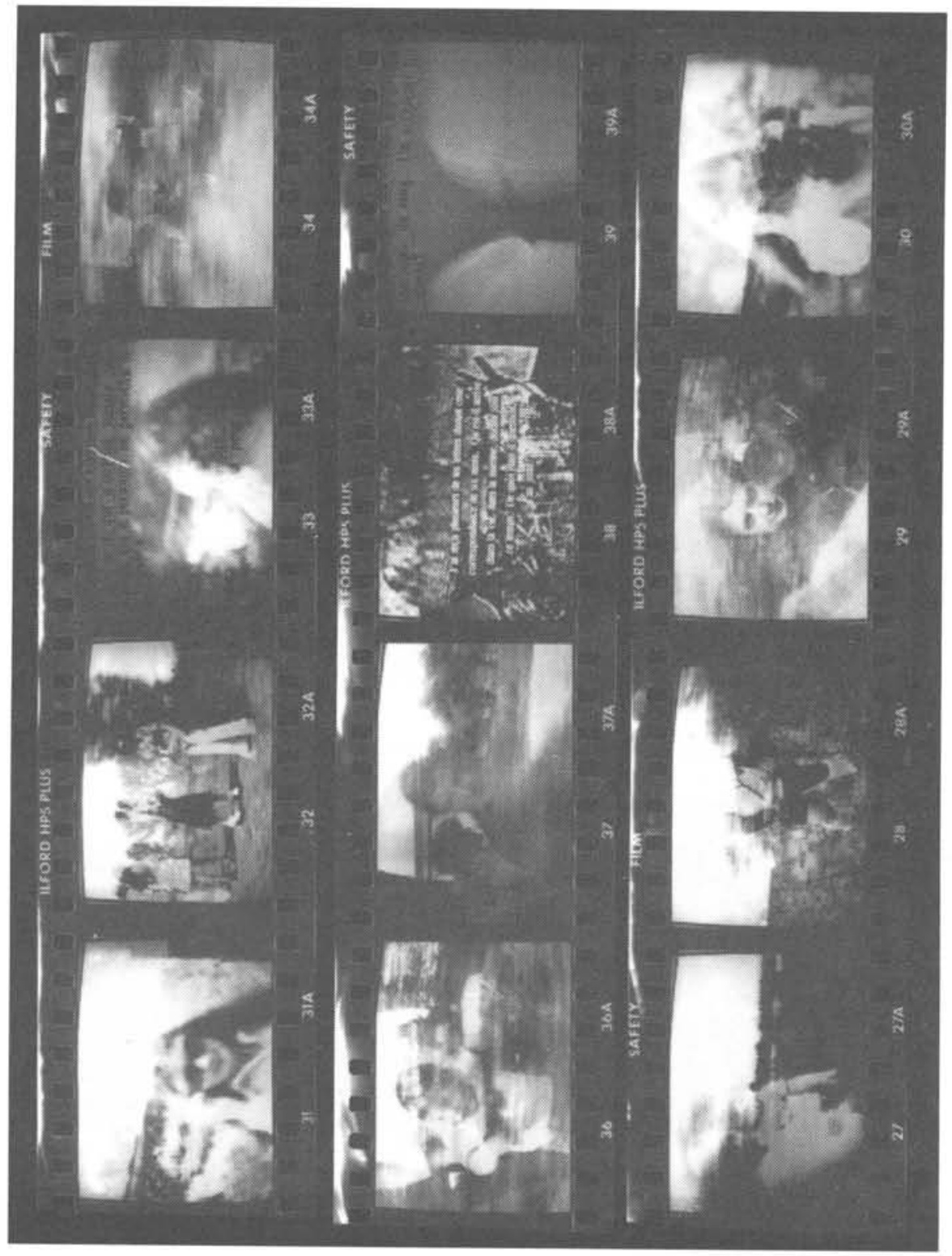

Gabrielle Schloesser, Correspondances interloquées, 1994 Exposition organisée par M. Langlois : Paysages de la vidéo. UQAM, septembre 1994 (art vidéo) 